\title{
INFLUENCE OF EXPOSURE TO PESTICIDES ON LIVER ENZYMES AND CHOLINESTERASE LEVELS IN MALE AGRICULTURE WORKERS
}

\author{
AWAD O.M. ${ }^{1}$ \\ EI-FIKI S.A. ${ }^{1}$ \\ ABOU-SHANAB R.A.I. ${ }^{2^{*}}$ \\ HASSANIN N.M.A. ${ }^{2}$ \\ ABD EI RAHMAN R. ${ }^{2}$
}

\author{
${ }^{1}$ High Institute of Public Health \\ University of Alexandria, Egypt \\ ${ }^{2}$ City of Scientific Research and Technology Applications \\ New Borg El Arab City, Alexandria, 21934, Egypt
}

Received: $12 / 11 / 2013$

Accepted: $12 / 11 / 2014$

*to whom all correspondence should be addressed:

Available online: 18/11/2014

e-mail: redaabushanab@yahoo.com

\section{ABSTRACT}

A significant increase in pesticide use has increased concerns about potentially adverse effects on human health and the environment. The study aimed to explore the effects of exposure to pesticides on the liver functions and acetycholinesterase levels in serum (AChES) and red blood cells (AChER) of 100

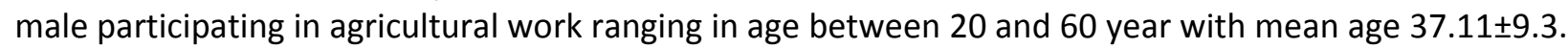
One hundred males matched for age and socio economic status were recruited as a control group to compare levels of alanine aminotransferase (ALT), aspartate aminotransferase (AST), bilriubin, alkaline phosphatase (ALP), total protein, AChES and AChER. The results indicate that AST, ALT and ALP were significantly $(P<0.05)$ increased in pesticide-exposed workers compared with control. There was also a highly significantly $(P<0.01)$ decrease in AChER among male agriculture workers compared with controls. At 10 - 50 times of pesticides applications there was a significantly $(P<0.05)$ decrease in AChER and increase in AST, ALT and ALP activity among exposed group. However, there was a negative correlation between AST, ALT, direct bilirubin, and AChES and age among control group and a positive correlation between ALT and AST and age among exposed group. According to the number of pesticide application, there was a positive correlation between AST, ALP, total and direct bilirubin and number of pesticide application. Agricultural villages in Egypt require more attention to decrease the percentage of literacy among the farmers and raise their health awareness.

Keywords: Cholinesterase, Pesticides exposure, Liver enzymes, Agriculture, Male

\section{Introduction}

Pesticides are ubiquitous in the environment and have significant economic, environmental and public health impact. Their usage has played a significant role in raising the yields of crops from agricultural land around the world. The population of Egypt was about 19 millions in 1947 and reached 57 millions in 1992. In 2003, the population has grown to about 70 millions with a growth rate of ca. $2.5 \%$ annually. At the same rate of growth, the population of Egypt after 15 year may exceed 100 millions (Mansour, 2004). Thus, the growth rate of the population in Egypt is a very serious problem, which might be a threat to the future of this country. Subsequently, the balance between population increase and production of enough food is therefore one of the most important and challenging problems facing Egypt today. So, the use of pesticides in agriculture was, and will remain for the foreseeing future, an essential component and a prerequisite for increasing productivity of the land. 
World-wide sales of crop protection chemicals in 1989 were projected to be about $\$ 21$ billion (Hunter, 1989). Since the mid 1960s, the quantity of pesticides used in Egypt and Africa has increased about fivefold. About 1 million tons have been injected into the Egyptian environment during the last 40 years (Amr, 1999). Exposure to pesticides may involve large segments of population, which include agriculture workers and their families, besides the general population who may be exposed through home application of pesticides or via residues on food (Quandt et al., 2004). A vast majority of the population in Egypt is engaged in agriculture and is therefore exposed to the pesticides used in agriculture (Amer et al., 2002; Abdel Rasoul et al., 2008).

Exposure to pesticides both occupationally and environmentally causes a range of human health problems. It is estimated that nearly 10,000 deaths annually to use of chemical pesticide worldwide, with about three-fourths of these occurring in developing countries (Horrigan et al., 2002). Exposure to pesticides results in acute and chronic health problems (Yassi et al., 2001). The potential risks to pesticides applicator or farm worker occupationally exposed pesticides are greater than the risks to someone in the general population exposed only to traces of pesticides in food and /or water (Amer et al., 2002). Exposure to low level of pesticides is known to produce a variety of biochemical changes, some of which may be responsible for the adverse biological effects in humans (Elhalwagy et al., 2009; Ibrahim et al., 2011). Conversely, some biochemical alterations may not necessarily lead to clinically recognizable symptoms, although all the biochemical responses can be used as markers of exposure or effect.

The aminotransferases are the most frequently utilized and specific indicators of hepatocellular necrosis. These enzymes-aspartate aminotransferase (AST) and alanine amino transferase (ALT) catalyze the transfer of the á amino acids of aspartate and alanine respectively to the á keto group of ketoglutaric acid. Alkaline phosphatases (ALP) are a family of zinc metaloenzymes, with a serine at the active center; they release inorganic phosphate from various organic orthophosphates and are present in nearly all tissues (Thapa and Anuj Walia, 2007). The liver enzyme has broad substrate specificity, including a variety of pesticide oxidations. It has been reported to be significantly lower in humans occupationally exposed to pesticides as compared to control (Zeinalov and Gorkin, 1990). Many researchers tried to correlate various enzymes with the harmful effects of pesticides, especially in the case of ALT, AST, ALP, and Acetylcholinesterase (AChE) (Altuntas et al., 2002; Ahmed and Mohammad, 2005; Remor et al., 2009; Vrioni et al., 2011; Dias et al., 2013). However, very little work has been done on this aspect in Egypt (Amer et al., 2002; Mansour, 2004; Abdel Rasoul et al., 2008). Therefore, analysis of blood samples of agriculture workers compared with control was done to find 1) the impact of pesticide exposure on liver enzymes and AChE levels among different age group, 2) number of pesticide application and its effect on liver functions and AChE activity, 3) Correlation between liver enzymes, AChE and age and number of pesticide application.

\section{Materials and methods}

\subsection{Study design and population}

This is a cross section comparative study. As pesticides have been linked with various chronic diseases, individuals presenting diabetes, neurological disorders, liver dysfunction, or any other chronic condition were excluded from the population studied in order to avoid any interference with the biochemical parameters measured. Prior to the study, all the individuals gave informed and written consent and completed a detailed questionnaire, covering standard demographic questions, habits (sports, food, drugs, tobacco, etc.), as well as occupational, medical and family history, duration of pesticides application, kind of pesticides and personal protective equipment (PPE) used.

The study used 100 male pesticides appliers (sprayers) ranging in age between 20 and 60 years (mean age: $37.11 \pm 9.3$ ) were recruited to participate in the study based on their potential for exposure to pesticides. They were from small villages (El-Oula, $n=50$ and Banger No. 25, $n=50$ ) at Banger El-Soukar 
agriculture sector, Alexandria, Egypt. The control group comprised 100 healthy male ranging in age between 20 and 60 year (mean age: $35.97 \pm 9.6$ ) from the same geographical area who had no history of exposure to chemicals or other potentially genotoxic substances. In order to avoid differences in environmental exposure to pesticide residues, they were from the same geographical setting than applicators, so that their socio-economic and nutrition status was very similar. Characteristics of exposed and non-exposed groups are summarized in Table 1.

\subsection{Sample collection and preparation}

After an overnight fasting period, two samples of venous blood were collected in tubes with clot activator and EDTA $(1 \mathrm{mg} / \mathrm{ml})$, respectively. Written consent was obtained from the subjects who agreed to participate, and they were allowed to drop out whenever they wanted. The samples were kept at $4{ }^{\circ} \mathrm{C}$ in a box with ice and transported to the laboratory. They were also protected from light to avoid enzymatic changes. Serum, plasma and erythrocytes were separated by centrifugation at $2000 \mathrm{rpm}$ for 15 min. Plasma and serum was stored at $-20{ }^{\circ} \mathrm{C}$ for biochemical analyses. Erythrocytes pellets were suspended and washed twice in Normal sterile saline (NSS) and diluted with an equal volume of saline (Hernández et al., 2005). Erythrocyte aliquots were diluted up to 1:100 in distilled water before storing overnight at $\left(-20^{\circ} \mathrm{C}\right)$.

\subsection{Biochemical assays}

Serum enzymes parameters were measured using Perkin Elmer UV/VIS spectrometer Lambda EZ201.

\subsubsection{Liver function tests}

Liver function tests comprising serum ALT, AST, ALP, and serum bilirubin (total and direct) were assayed according to Tietz, 1990. Total protein in serum was quantified by the procedure of Lowry et al. (1951), using bovine serum albumin (BSA) standard.

\subsubsection{Acetyl cholinesterase}

Acetyl cholinesterase activity in serum (AChES) and erythrocyte (AChER) was estimated spectrophotometrically at $405 \mathrm{~nm}$ by the method of Ellman et al. (1961), using acetylthiocholine iodide as the substrate. At pH 7.7, the cholinesterase catalyses esters choline hydrolyses as propionylcholine, and it liberates sulfidryl group thiocholine. The thiocoline reacts with acid 5,5'-ditiobis-2-nitrobenzoic (DTNB) producing a yellow compound directly proportional to the enzyme activity which is measured by spectrometer at $405 \mathrm{~nm}$. Unit of enzyme activity was expressed as micromoles acetylthiocholine hydrolysed/min/ml blood fraction.

\subsection{Statistical methods}

All data are represented in tables as mean \pm standard error (mean $\pm \mathrm{SE}$ ). Statistical analysis was performed using the SPSS package system version 11 (SPSS Inc., Chicago, IL, USA).

\section{Results and discussion}

\subsection{Socio-demographic characteristics of male agriculture workers}

Table 1 shows that about 40\% of the workers in Banger No. 25 and El Oula villages were illiterate. University graduates represented only $7 \%$ of the studied agriculture workers. The mean time of pesticide exposures and age (in year) in all farm workers were $11 \pm 6.05$ and $37.11 \pm 9.3$ year, respectively. All studied populations were not use personal protective equipment (PPE). The use of a wide range of pesticides - mostly of "moderately hazardous" to "slightly hazardous" category- among our study farmers (Table 2). Food and Agriculture Organization (FAO) recommends that World Health Organization (WHO) Ib (Highly hazardous) pesticides should not be used in developing countries (PAN, 2001). It also suggests that class II (Moderately hazardous) pesticides be avoided. But the practice of spraying these "powerful" pesticides continues. Preliminary results of environmental sampling tests done in the study 
area support this statement (Hassanin, 2009). Individuals are frequently exposed to many different pesticides or mixtures of pesticides, either simultaneously or serially, making it difficult to identify effects of particular agents. The relationship of pesticide-related cytotoxicity to overt clinical organ disease is still unresolved. In this regard, biomarkers may be used to detect the effects of pesticides before adverse clinical health effects occur.

Table 1: Characteristics of the study population

\begin{tabular}{ccccc}
\hline & & \multicolumn{3}{c}{ Exposed farm workers } \\
\cline { 3 - 4 } Characteristic & Controls & \multicolumn{2}{c}{ Village } & All farm workers \\
\cline { 3 - 4 } & & 50 & 50 & 100 \\
\cline { 3 - 4 } No. of subjects & 100 & El Oula & Bangar No.25 & \\
Age (in years) [mean \pm SD] & $35.97 \pm 9.6$ & $35.5 \pm 10.05$ & $38.49 \pm 8.5$ & $37.11 \pm 9.3$ \\
Years of exposure [mean \pm SD] & - & $5 \pm 2.8$ & $15 \pm 3.7$ & $11 \pm 6.05$ \\
Personal protective & & & & \\
equipment & - & & & \\
Yes & - & $50(100 \%)$ & $50(100 \%)$ & $100(100 \%)$ \\
No & & & & \\
Education & 25 & 22 & 18 & $50 \%$ \\
Illiterate & 33 & 24 & 29 & $7 \%$ \\
Secondary school & 42 & 4 & 3 & 5 \\
University graduate & & & & \\
\hline
\end{tabular}

3.2. Pesticides exposure and liver functions among different age groups

Hepatotoxicity was monitored by quantitative analysis of the serum ALT, AST, ALP, bilirubin, AChES, and AChER and protein, which was used as the biochemical markers of liver damages. Liver enzymes (AST, ALT and ALP) were significantly $(P<0.05)$ increased in pesticide-exposed workers compared with control among age group $20<60$. There was a highly significantly $(P<0.01)$ decreased in direct bilirubin and significantly $(P<0.05)$ decreased in total protein compared with control. In the mean time there was no significant difference in total bilirubin content among exposed group as compared to control group (Table 3).

In age group $20<30$ there was a highly significantly $(P<0.01)$ increased and decreased in ALP and direct bilirubin, respectively, in exposed group compared with control. There was a significantly $(P<0.05)$ increased in ALT, AST, and ALP and highly significantly $(P<0.01)$ decreased in direct bilirubin in exposed group compared with control at the same age $(30<40)$. Among age group $(40<50)$ we observed that AST was significantly $(P<0.05)$ increased and direct bilirubin was highly significant $(P<0.01)$ in exposed person compared with control. There was a highly significantly $(P<0.01)$ increased in ALT in exposed group compared with control at age $50<60$. Protein concentration was significantly $(P<0.05)$ decreased in exposed group $(40<50)$ compared with control at the same age (Table 3). An increased risk of liver dysfunction was observed in Air Force veterans responsible for the aerial spraying of herbicides in Vietnam, the effect being due primarily to increased AST, ALT, or LDH (Michalek et al., 2001). "In vitro" studies have found that glyphosate and paraquat are able to inhibit certain enzyme activities: ALT, AST, lactate dehydrogenase (LDH), and acetyl cholinesterase (AChE) (El-Demerdash et al., 2001). Experimental studies in rats have reported significant changes in all these enzyme activities after subchronic administration of mancozeb in a dose-dependent manner (Kackar et al., 1999). Also, chronic exposure of rats and mice to OPs led to increased levels of serum ALT and AST (Gomes et al., 1999). Some pesticides, such as paraquat and glyphosate, have been reported to cause inhibition in the activity of serum AST and LDH, while other pesticides (OPs, organochlorines, and pyrethroids) are able to cause inhibition of LDH (El-Demerdash et al., 2001; Podprasart et al., 2007). Azmi et al., (2006) reported that a significant increase in the enzyme levels (ALT, AST and ALP) in different fruit and vegetable farm-station 
workers exposed to pesticides. The activities of serum transaminases may be raised due to increased release from non-liver tissue sources in various pathologies (Rej., 1989). Pesticide exposure causes leakage of cytosolic enzymes from hepatocytes and other body organs (Dewan et al., 2004). A high degree of abnormal liver function in agriculture workers may indicate toxic effects of pesticides and the presence of pesticides residues in blood. Altered liver enzyme activities have been reported among occupational workers exposed to organophosphorus pesticides alone or in combination with organochlorines (Amr, 1999). Ibrahim et al. (2011), reported that there was a significant elevation in serum liver enzymes (AST and ALT) in agriculture workers compared to the controls. Increased serum ALP activity may result from physiological or pathological enzyme production and release from non-liver tissue sources (Van Hoof and Broe, 1994). Fahimul-Haq et al. (2013) reported that the T. Bilirubin and D. Bilirubin in both groups were not only within the normal range but were also comparatively close to upper normal limit in pesticide industrial workers. High Bilirubin level after exposure to pesticides has also been reported by other researchers (Scharschmidt, 2000). It might be attributed to prolonged exposure to pesticides which disturbed the normal red blood cell metabolism, affecting the hepatic dysfunction and increased the level of bilirubin in the blood thereby causing hyperbilirubinemia which might be due to production of more bilirubin than the normal liver can excrete.

Table 2: Pesticides used by the exposed subjects

\begin{tabular}{cccc}
\hline Pesticide & Common name & Chemical class & WHO \\
\hline Insecticides & Chlorpyrifos & Organophosphorus compound & II \\
\hline & Profenofos & Organophosphorus compound & II \\
\hline Glyphosate & Organophosphorus compound & III \\
\hline Penconazole & Organophosphorus compound & III \\
\hline Thiobencarb & Thiocarbamate & II
\end{tabular}

WHO (World Health Organization); $\mathrm{II}=$ moderately hazardous and III= slightly hazardous

\subsection{Pesticides exposure and cholinesterase levels among different age groups}

There was a highly significantly $(P<0.01)$ decreased in the concentration of cholinesterase in red blood cell (AChER) of exposed groups $(5155 \pm 1372)$ compared to control $(6073 \pm 2688)$ in age group from 20 to 60 year. There was no significant difference in the level of cholinesterase in serum (AChES) of exposed group as compared to control within the same age group (Table 3). At the age groups $20<30$ and $50<60$ year, there were no significant differences in acetycholinestrase activity in AChER and AChES among exposed group as compared to control group. On the other hand there was a significantly $(P<0.05)$ decreased in AChER and AChES activities in exposed age groups $(30<40$ and $40<50)$ compared with control (Table 3).

Results in the present study also referred that there was a highly significantly decreased in AChER among exposed group as compared to control group, while there was no significant difference in AChES in age group (20>60). Hazarika et al., (2003) reported that anilofos or malathion or their combination was significantly decreased AChER, plasma blood and brain as compared with control values. These finding are in agreement with the present study. According to Rawi, (1984), the pyrethroid decamethrin caused prolonged decrease in AChE activity in rats after single dose administration. Indeed, the main effects of pyrethroids are on sodium and chloride channels, as they modify the gating characteristics of voltage sensitive sodium channels to delay their closure (Bardberry et al., 2005). These agents increase $\mathrm{Na}^{+}$influx into synaptic terminals and create a hypopolarized and hyperirritable synaptic membrane, which in turn increases the release of the neurotransmitter acetylcholine (Rao and Rao, 1993).

\subsection{Number of pesticide application and its effect on liver functions and acety/cholinesterase activity}

Pesticide exposure can cause a variety of human health problems, both chronic and acute. Chronic effects are typically the result of low levels of exposure over a long period of time. These can occur even if there are no acute or immediate effects. Major health impacts from chronic exposure include cancers, reproductive and endocrine disruption, neurological damage, and immune system dysfunction (Sanborn 
et al., 2002). According to the WHO, long-term regular exposure to pesticides causes approximately 772,000 new cases of diseases every year (WHO and UNEP, 1990). There are very few studies on the long-term human health impacts of pesticides in Egypt. Many of the studies on pesticides in Egypt relate to pesticide residues in food, water and human bodies (Amer et al., 2002; Abdel-Halim et al., 2006; Sallam and Morshedy, 2008).

There was a significantly $(P<0.05)$ increased in AST, ALT and ALP activity among exposed group as compared to control group at 10 - 50 times of pesticide applications. While, there was a highly significantly $(P<0.01)$ decreased in total protein, and direct bilirubin content. At $50-100$ times of pesticide applications there was no significant difference in AST activity, total bilirubine and protein content among exposed group as compared to control group (Table 4). However, there was a highly significantly $(P<0.01)$ increased in ALT and ALP activity and highly significantly $(P<0.01)$ decreased in direct bilirubine among exposed group compared with control group at the same conditions. As a result of increase the time of pesticide application (more than 100 times), there was no significant difference in AST, ALT, and total bilirubine among exposed group as compared to control group. While there was a significant decrease $(P<0.05)$ in direct bilirubine and total protein content but there was a highly significantly $(P<0.01)$ increased in ALP activity among exposed group as compared to control group (Table 4). High level of ALP was also reported by many researchers (Paulino et al., 1996; Mani et al., 2001; Altuntas et al., 2002) in the persons involved in pesticide spraying. High level of AST and ALT was also reported by other researchers in persons exposed to pesticides (Sahin et al., 2002; Rahman and Siddiqui, 2003; Azmi et al., 2006).

At 10 - 50 times of pesticides applications there was a significant decrease $(P<0.05)$ in acetylcholinestrase in red blood cell (AChER) among exposed group as compared with control group, while at $50-100$ and more than 100 time of pesticides applications there was no significant difference in AChER among exposed group. In the mean time at 10 -50, 50 -100 and more than 100 times of pesticides applications there was no significant difference in acetycholinestrase in serum (AChES) among exposed group as compared to control. The changes in cholinesterase levels were found to be significantly associated with pesticides exposure. The increase in individual cholinesterase levels was statistically significantly associated with environmental exposure to aerial pesticide application (Dalvie and London, 2006).

\subsection{Correlation between liver functions, AChE and age and number of pesticide application}

There was a negative correlation between AST, ALT, direct bilirubin, and AChES and age among control group and a positive correlation between ALT, and AST and age among exposed group. A positive correlation was found between total bilirubin and age in control and exposed group. At the same time there was a highly significantly $(P<0.01)$ negative correlation between ALP and age among exposed group, while a positive correlation with age among control group. There was a positive correlation between AChER and age among control group and a negative correlation among exposed group. However there was a negative correlation between AChES, AChER and age in control and exposed (Table 5). According to the number of pesticide application, there was a positive correlation between AST, ALP, Total and direct bilirubin and number of pesticide application. On the other hand there was a negative correlation between ALT, total protein, AChES and AChER and number of pesticide application among exposed group (Table 6). Correlation between enzymes and pesticides has been reported by various workers, e.g., Misra et al., (1985) who reported the high level of AST and ALT in the blood of occupational workers chronically exposed to organophosphate pesticides. Carvalho (1991), reported the increased level of AST and ALT in the persons due to occupational and environmental exposure of organochlorine insecticides in the state of Bahia, Naqvi and Khan (1993), correlated the inhibition of ALP by phosphine in Tribolium castaneum, which may be due to poisoning effect of Phosphine. Goel et al. (2000) also correlated a significant increase in the levels of various serum and liver marker enzymes such as ALP, AST and ALT due to the effect of chlorphyrifos. Rahman and Siddiqui, (2003), also showed the positive correlation between the enzyme activity (AST and ALT) in different tissues of rats exposed to phosphorothionate. 
Table 3: Effects of chronic exposure to a mixture of pesticides on liver functions and acetylcholinestrase activity in male at different age

\begin{tabular}{|c|c|c|c|c|c|c|c|c|c|c|c|c|c|c|c|}
\hline \multirow{3}{*}{ Parameters } & \multicolumn{15}{|c|}{ Age groups (in year) } \\
\hline & \multicolumn{3}{|c|}{$20-30$} & \multicolumn{3}{|c|}{$30-40$} & \multicolumn{3}{|c|}{$40-50$} & \multicolumn{3}{|c|}{$50-60$} & \multicolumn{3}{|c|}{$20-60$} \\
\hline & $C(n=34)$ & Exp. $(n=24)$ & $t(P)$ & $C(n=37)$ & Exp. $(n=31)$ & $t(P)$ & $C(n=19)$ & $\operatorname{Exp}(n=39)$ & $t(P)$ & $C(n=10)$ & $\operatorname{Exp}(n=6)$ & $t(P)$ & $C(n=100)$ & $\operatorname{Exp}(n=100)$ & $t(P)$ \\
\hline $\operatorname{ALT}(\mathrm{U} / \mathrm{I})$ & $1.69 \pm 3.17$ & $1.98 \pm 3.09$ & $\begin{array}{c}0.35 \\
(0.72)\end{array}$ & $2.80 \pm 3.63$ & $3.91 \pm 4.47$ & $\begin{array}{c}* 2.10 \\
(0.05)\end{array}$ & $1.37 \pm 4.05$ & $7.34 \pm 15.84$ & $\begin{array}{c}1.60 \\
(0.09)\end{array}$ & $0.90 \pm 1.79$ & $7.12 \pm 8.01$ & $\begin{array}{c}2.40^{* *} \\
(0.005)\end{array}$ & $1.98 \pm 8.01$ & $4.97 \pm 10.62$ & $\begin{array}{c}2.6^{*} \\
(0.007)\end{array}$ \\
\hline AST (U/I) & $8.96 \pm 10.14$ & $7.59 \pm 9.98$ & $\begin{array}{c}-0.51 \\
(0.581)\end{array}$ & $6.53 \pm 6.78$ & $10.66 \pm 9.75$ & $\begin{array}{c}2.05^{*} \\
(0.045)\end{array}$ & $4.77 \pm 6.83$ & $9.49 \pm 7.53$ & $\begin{array}{c}2.30^{*} \\
(0.025)\end{array}$ & $7.15 \pm 8.70$ & $8.05 \pm 13.95$ & $\begin{array}{c}0.16 \\
(0.34)\end{array}$ & $7.08 \pm 8.29$ & $9.31 \pm 9.22$ & $\begin{array}{c}1.7^{*} \\
(0.027)\end{array}$ \\
\hline ALP (IU/I) & $9.10 \pm 4.04$ & $\begin{array}{c}25.39 \pm 21.9 \\
6\end{array}$ & $\begin{array}{l}4.20^{* *} \\
(0.001)\end{array}$ & $12.02 \pm 6.12$ & $16.66 \pm 7.56$ & $\begin{array}{c}2.70^{*} \\
(0.031)\end{array}$ & $15.41 \pm 9.16$ & $16.07 \pm 6.58$ & $\begin{array}{c}0.32 \\
(0.132)\end{array}$ & $14.85 \pm 7.28$ & $16.32 \pm 4.14$ & $\begin{array}{c}0.44 \\
(0.43)\end{array}$ & $11.95 \pm 6.71$ & $18.51 \pm 12.73$ & $\begin{array}{c}4.5^{*} \\
(0.050)\end{array}$ \\
\hline $\begin{array}{c}\text { T. bilirubin } \\
\text { (mg/dl) }\end{array}$ & $0.45 \pm 0.34$ & $0.45 \pm 0.18$ & $\begin{array}{l}0.042 \\
(0.41)\end{array}$ & $0.55 \pm 0.38$ & $0.60 \pm 0.23$ & $\begin{array}{c}0.63 \\
(0.110)\end{array}$ & $0.52 \pm 0.39$ & $0.56 \pm 0.26$ & $\begin{array}{c}0.00 \\
(0)\end{array}$ & $0.65 \pm .0 .33$ & $0.60 \pm 0.35$ & $\begin{array}{l}0.30 \\
(0.7)\end{array}$ & $0.52 \pm 0.37$ & $0.55 \pm 0.24$ & $\begin{array}{l}-0.68 \\
(0.53)\end{array}$ \\
\hline $\begin{array}{c}\text { D. bilirubin } \\
\text { (mg/dl) }\end{array}$ & $0.21 \pm .0 .16$ & $0.03 \pm .0 .01$ & $\begin{array}{l}5.40^{* *} \\
(0.000)\end{array}$ & $0.28 \pm 0.25$ & $0.04 \pm 0.01$ & $\begin{array}{l}-5.30^{* *} \\
(0.007)\end{array}$ & $0.23 \pm 0.21$ & $0.04 \pm 0.02$ & $\begin{array}{l}-5.30^{* *} \\
(0.008)\end{array}$ & $0.19 \pm 0.11$ & $0.04 \pm 0.02$ & $\begin{array}{c}-2.90^{*} \\
(0.014)\end{array}$ & $0.24 \pm 0.20$ & $0.04 \pm 0.01$ & $\begin{array}{c}9.9^{* *} \\
(0.001)\end{array}$ \\
\hline $\begin{array}{l}\text { T. protein } \\
\text { (g/dl) }\end{array}$ & $8.03 \pm 1.29$ & $7.55 \pm 1.30$ & $\begin{array}{c}-1.30 \\
(0.981)\end{array}$ & $8.91 \pm 1.47$ & $8.21 \pm 4.72$ & $\begin{array}{l}-0.86 \\
(0.27)\end{array}$ & $8.87 \pm 1.20$ & $7.05 \pm 1.28$ & $\begin{array}{c}3.50^{*} \\
(0.007)\end{array}$ & $8.11 \pm 1.82$ & $8.40 \pm 3.78$ & $\begin{array}{c}0.211 \\
(0.199)\end{array}$ & $8.52 \pm 1.44$ & $7.61 \pm 2.96$ & $\begin{array}{c}2.7^{*} \\
(0.024)\end{array}$ \\
\hline AChES (U/I) & $4459.5 \pm 1739$ & $5945 \pm 1480$ & $\begin{array}{c}1.40 \\
(0.027)\end{array}$ & $7411 \pm 1203$ & $4354 \pm 2266$ & $\begin{array}{c}7.10^{*} \\
(0.023)\end{array}$ & $5046 \pm 1703$ & $3968 \pm 2303$ & $\begin{array}{c}1.80^{*} \\
(0.024)\end{array}$ & $3844.5 \pm 1818$ & $3650 \pm 1115$ & $\begin{array}{c}-0.23 \\
(0.818)\end{array}$ & $5601 \pm 7522$ & $4543 \pm 3752$ & $\begin{array}{l}1.25 \\
(0.2)\end{array}$ \\
\hline $\begin{array}{c}\text { AChER } \\
(\mathrm{U} / \mathrm{I})\end{array}$ & $5697 \pm 3697$ & $5083 \pm 1344$ & $\begin{array}{c}-0.77 \\
(0.134)\end{array}$ & $6403.9 \pm 2179$ & $5298 \pm 1535$ & $\begin{array}{l}-2.30^{*} \\
(0.028)\end{array}$ & $6009 \pm 1749$ & $5138 \pm 1242$ & $\begin{array}{l}-2.10^{*} \\
(0.033\end{array}$ & $6256 \pm 1805$ & $4822 \pm 1671$ & $\begin{array}{c}-1.50 \\
(0.137)\end{array}$ & $6073 \pm 2688$ & $5155 \pm 1372$ & $\begin{array}{l}-3.04^{* *} \\
(0.003)\end{array}$ \\
\hline
\end{tabular}
difference was highly significant at the $\mathrm{P}<0.01$ (t. test); AChES= Acetylcholinestrase activity in serum and Acetylcholinestrase activity in erythrocytes (AChER).

Table 4: Effect of chronic exposure to a mixture of pesticides on liver functions and acetylcholinestrase according to the number of pesticide applications

\begin{tabular}{|c|c|c|c|c|c|c|c|}
\hline \multirow{3}{*}{ Parameters } & Control & \multicolumn{6}{|c|}{ Exposed } \\
\hline & \multicolumn{7}{|c|}{ Number of pesticide applications } \\
\hline & $0(n=100)$ & $10-50(n=81)$ & $t(P)$ & $50-100(n=13)$ & $t(P)$ & Over $100(n=6)$ & $t(P)$ \\
\hline $\operatorname{ALT}(\mathrm{U} / \mathrm{I})$ & $1.98 \pm 3.45$ & $5.08 \pm 11.62$ & $2.53 *(0.012)$ & $4.86 \pm 4.71$ & $2.7^{* *}(0.007)$ & $3.81 \pm 4.44$ & $1.3(0.219)$ \\
\hline AST (U/I) & $7.08 \pm 8.29$ & $9.39 \pm 9.35$ & $1.75 *(0.030)$ & $7.8 \pm 7.1$ & $0.333(0.366)$ & $11.43 \pm 12.28$ & $1.2(0.228)$ \\
\hline $\operatorname{ALP}(I U / I)$ & $11.95 \pm 6.71$ & $18.55 \pm 13.05$ & $4.3 *(0.047)$ & $17.97 \pm 14.03$ & $2.6^{* *}(0.011)$ & $19.08 \pm 2.86$ & $2.57^{* *}(0.011)$ \\
\hline T. bilirubin (mg/dl) & $0.52 \pm .0 .37$ & $0.55 \pm 0.24$ & $0.567(0.571)$ & $0.53 \pm 0.23$ & $0.079(0.112)$ & $0.60 \pm 0.30$ & $0.493(0.623)$ \\
\hline D. bilirubin $(\mathrm{mg} / \mathrm{dl})$ & $0.24 \pm 0.20$ & $0.04 \pm 0.01$ & $-8.6 * *(0.001)$ & $0.045 \pm .018$ & $-3.4^{* *}(0.001)$ & $0.04 \pm .02$ & $-2.29 *(0.024)$ \\
\hline T. protein (g/dl) & $8.52 \pm 1.44$ & $7.38 \pm 1.57$ & $-5.06 * *(0.002)$ & $9.35 \pm 7.21$ & $1.02(0.307)$ & $6.90 \pm 0.48$ & $-2.73^{* *}(0.007)$ \\
\hline AChES (IU/I) & $5601 \pm 7522$ & $4610 \pm 3973$ & $-1.07(0.286)$ & $5055 \pm 2821$ & $-0.25(0.798)$ & $2530 \pm 1221$ & $-0.99(0.322)$ \\
\hline AChEE (IU/I) & $6073 \pm 2688$ & $5110 \pm 1345$ & $-2.9 * *(0.007)$ & $5774 \pm 1411$ & $-0.39(0.694)$ & $4431 \pm 1369$ & $-1.48(0.142)$ \\
\hline
\end{tabular}

*The mean difference was significant at the $\mathrm{P}<0.05$ level (t. test); ${ }^{* *}$ The mean difference was highly significant at the $\mathrm{P}<0.01$ (t. test) 
Table 5: Correlation between liver functions, total protein and AChE and Age in exposed and control groups

\begin{tabular}{ccccc}
\hline Parameters & \multicolumn{4}{c}{ Age $(20-60$ year $)$} \\
\cline { 2 - 5 } & Control & Sig & Exposed & Sig \\
\hline AST (U/l) & -0.103 & 0.30 & 0.133 & 0.188 \\
ALT (U/l) & -0.101 & 0.318 & 0.175 & 0.081 \\
T. bili (mg/dl) & 0.112 & 0.266 & $0.216^{*}$ & 0.031 \\
D. bili (mg/dl) & -0.036 & 0.723 & -0.036 & 0.042 \\
ALP (IU/L) & 0.307 & 0.002 & $-0.289^{* *}$ & 0.004 \\
T. protein (g/dl) & 0.070 & 0.489 & -0.046 & 0.648 \\
AChES (IU/l) & -0.021 & 0.833 & $-0.220^{*}$ & 0.028 \\
AChER (IU/I) & 0.053 & 0.600 & -0.033 & 0.747
\end{tabular}

${ }^{*}$ The mean difference was significant at the $\mathrm{P}<0.05$ level (t. test); ${ }^{* *}$ The mean difference was highly significant at the $\mathrm{P}<0.01$ (t. test)

Table 6: Correlation between liver functions, total protein and AChE and number of pesticides application

\begin{tabular}{ccc}
\hline Parameters & \multicolumn{2}{c}{ Number of applications $(10<100$ times $)$} \\
\cline { 2 - 3 } & Exposed & Sig \\
\hline AST (U/l) & 0.037 & 0.717 \\
ALT (U/l) & -0.091 & 0.370 \\
T. Bili $(\mathrm{mg} / \mathrm{dl})$ & 0.035 & 0.730 \\
D. Bili $(\mathrm{mg} / \mathrm{dl})$ & 0.06 & 0.495 \\
ALP (IU/L) & 0.018 & 0.863 \\
T. Protein (g/dl) & -0.020 & 0.842 \\
AChES (IU/I) & -0.046 & 0.652 \\
AChER (IU/I) & -0.034 & 0.739 \\
\hline
\end{tabular}

\section{Conclusions}

The present study revealed that certain enzymes (AST, ALT, and ALP), as well as total protein, bilirubin and cholinesterase activity in serum and red blood cells, are to some extent influenced by pesticide exposure. Most farmers in our study were not aware of the health hazards caused by the inappropriate handling of pesticides. Awareness needs to be created on use of personal protective measures among farmers, while handling pesticides. Farmers needs to be encouraged to reduce, if not eliminate the use of pesticides, with the introduction of incentives to the farmers to help them shift from synthetic pesticides to bio-pesticides and organic farming.

\section{References}

Abdel-Halim K.Y., Salama A.K., El-khateeb E.N. and Bakry N.M. (2006), Organophosphorus pollutants (OPP) in aquatic environment at Damietta Governorate, Egypt: Implications for monitoring and biomarker responses, Chemosphere, 63, 1491-1498.

Abdel Rasoul G.M., Abou Salem M.E., Mechael A.A., Hendy O.M., Rohlman D.S. and Ismail A.A. (2008), Effects of occupational pesticide exposure on children applying pesticides, NeuroToxicology, 29, 833-838.

Ahmed O.A.H. and Mohammad F.K. (2005), A simplified eletrometric technique for rapid measurement of human blood cholinesterase activity, The Int. J. Toxicol., 2, 1-13.

Amr M.M. (1999), Pesticide monitoring and its health problems in Egypt, a third world country, Toxicol Lett., 107,1-13. 
Amer M.M., Metwalli M. and Abu El-Magd Y. (2002), Skin diseases and enzymatic antoxidant activity among workers exposed to pesticides, Eastern Mediterranean Health J., 8, 1- 9.

Azmi M.A., Naqvi S.N.H., Azmi M.A. and Aslam M. (2006), Effect of pesticide residues on health and different enzyme levels in the blood of farm workers from Gadap (rural area) Karachi-Pakistan, Chemosphere, 64, 1739-1744.

Bardberry S.M., Cage S.A., Proudfoot A.T. and Allister V.J. (2005), Poisoning due to pyrethroids, Toxicol. Rev., 24, 93-106.

Carvalho W.A. (1991), Risk factors related with occupational and environmental exposure to organochlorine insecticides in the state of Bahia, Brazil. Bol. Oficina. Sanit. Panam., 111, 512-524.

Dalvie M.A. and London L. (2006), The impact of aerial application of organophosphates on the cholinesterase levels of rural residents in the Vaalharts district, Northern Cape Province, South Africa, Environ. Res., 102, 326-332.

Dewan A., Bhatnagar V.K., Mathur M.L. Chakma T., Kashyab R., Sadhu H.G., Sinha S.N. and Saiyed H.N., (2004), Repeated episodes of endosulfan poisoning, J. Toxicol Clin Toxicol., 42,363-369.

Dias E., Mariana G., Catarina D., Elmano R., Simone M. and Maria P. (2013), Subacute Effects of the Thiodicarb Pesticide on Target Organs of Male Wistar Rats: Biochemical, Histological, and Flow Cytometry Studies, J. Toxicol. Environ. Health A, 76, 533-539.

El-Demerdash F.M., Yousef M.I. and Elagamy E.I. (2001), Influence of paraquat, glyphosate, and cadmium on the activity of some serum enzymes and protein electrophoretic behavior (in vitro), J. Environ. Sci. Health B., $36,29-42$.

Elhalwagy M.E.A. and Zaki N.I. (2009), Comparative study on pesticide mixture of organophosphorus and pyrethroid in commercial formulation, Environ. Toxicol. Pharmacol., 28,219-224.

Ellman G.L., Courtney D.K., Andres J.V. and Featherstone R.M. (1961), A new rapid colorimetric determinacion of acetylcholinesterase activity, Biochem. Pharmacol., 7, 88-95.

Gomes J., Dawodu A.H., Lloyd O., Revitt D.M. and Anilal S.V. (1999), Hepatic injury and disturbed amino acid metabolism in mice following prolonged exposure to organophosphorus pesticides, Human Exp. Toxicol., 18, 33-37.

Hassanin N.M.A. (2009), Some biological parameters among rural area population exposed to pesticides, Master Thesis, Public Health Institute, Alexandria University, Egypt.

Hazarika A., Sarkar S.N., Hajare S., Kataria M. and Malik J.K. (2003), Influence of malathion pretreatment on the toxicity of anilofos in male rates: a biochemical interaction study, Toxicol., 185, 1-8.

Hernández A.F., López O., Rodrigo L., Gil F., Pena G., Serrano J.L., Parrón T., Alvarez J.C., Lorente J.A. and Pla A. (2005), Changes in erythrocyte enzymes in humans long-term exposed to pesticides Influence of several markers of individual susceptibility, Toxicol. Lett., 159, 13-21.

Horrigan L., Lawrence R.S. and Walker P. (2002), How sustainable agriculture can address the environmental and human health harms of industrial agriculture, Environ Health Perspect., 110, 445-56.

Hunter D. (1989), Pesticides: a bumper year ahead, Chem. Week Feb. 8, 7.

Ibrahim K.S., Amer N.M., El-Tahlawy E.M. and Abd Allah H.M. (2011), Reporoductive outcome, hormone levels and liver enzymes in agricultural female workers, J Adv Res. 2, 185-189.

Kackar R., Srivastava M.K. and Raizada R.B. (1999), Assessment of toxicological effects of mancozeb in male rates after chromic exposure, Indian J. Exp. Biol., 37, 553-559.

Lowry O.H., Roserbrough N.J., Farr A.L. and Randall R.J. (1951), Protein measurement with follin phenol reagent, J. Biol. Chem., 193, 265-275.

Mansour S.A. (2004), Pesticide exposure-Egyptian scene, J. Toxicol., 198, 91-115.

Michalek J.E. Ketchum N.S. and Longnecker M.P. (2001), Serum dioxin and hepatic abnormalities in veterans of Operation Ranch Hand, Ann. Epidemiol., 11, 304-311.

Misra U.K., Nag D., Bhushan V. and Ray P.K. (1985), Clinical and biochemical changes in chronically exposed organophosphate workers, Toxicol. Lett., 244, 187-193. 
Naqvi S.N.H. and Khan S.A. (1993), Effect of different doses of phosphine on the alkaline phosphatase activity in Tribolium castaneum Herbst, Pakistan J. Entomol. Karachi, 8, 15-27.

PAN (2001), The List of the Lists: A Catalogue of Lists of Pesticides Identifying those Associated with Particularly Harmful Health or Environmental Impacts, Pesticide Action Network, 3 November, p. 9.

Paulino C.A., Guerra J.L., Oliveira G.H. and Palermo-Neto J. (1996), Acute, subchronic and chronic 2,4-dichlorophenoxyacetic acid (2,4-D) intoxication in rats, Vet. Hum. Toxicol., 38, 348-352.

Podprasart V., Satayavivad J., Riengrojpitak S., Wilairat P., Wananukul W. and Chavalittumrong P. (2007), No direct hepatotoxic potential following a multiple-low dose paraquat exposure in rat as related to its bioaccumulation, Toxicol. Let., 170,193-202.

Quandt S.A., Arcury T.A., Roa P., Snively B.M., Camann D.E., Doran A.M., Yau A.Y., Hoppin J.A. and Jackson D.S. (2004), Agricultural and residential pesticides in wipe samples from farm worker family residences in North Carolina and Virginia, Environ. Health Perspect., 112, 382-387.

Rahman M.F. and Siddiqui M.K. (2003), Biochemical enzyme activity in different tissues of rats exposed to a novel phosphorothionate (RPRV), J. Environ. Sci. Health, 38, 59-71.

Rao G. and Rao K. (1993), Inhibition of monoamine oxidase-A of rat brain by pyrethroids: an in vitro kinetic study, Mol. Cell Biochem., 124, 107-114.

Rawi S.M. (1984), Effect of two pesticides (Hostathion and Decamothrin) on some amino acids and some enzymes in the central nervous system of albino rat (Rattus norvegicus). A Thesis submitted for Ph.D. degree, Faculty of Science, Cairo University, Egypt.

Rej R. (1989), Aminotransferases in disease, Clin. Lab. Med., 9, 667-687.

Remor A.P., Totti C.C., Moreira D.A., Dutra G.P., Heuser V.D. and Boeira J.M. (2009), Occupational exposure of farm workers to pesticides: Biochemical parameters and evaluation of genotoxicity, Environ. Int. 35, 273-278.

Sahin I., Onbasi K., Sahin H., Karakaya C., Ustun Y. and Noyan T. (2002), The prevalence of pancreatitis in organophosphate poisoning, Hum. Exp. Toxicol., 21, 175-177.

Sallam K.I. and Morshedy A.E.M.A. (2008), Organochlorine pesticides in camel, cattle and sheep carcasses slaughtered in Sharkia Province, Egypt, Food Chem., 108, 154-164.

Sanborn M.D., Cole D., Abelsohn A. and Weir E. (2002), Identifying and managing adverse environmental health effects: 4. Pesticides, CMAJ, 166, 1431-1436.

Scharschmidt B.F. (2000), Bilirubin metabolism, hyperbilirubinemia, and approach to the jaundiced patient, in: L. Goldman, J.C. Bennett (Eds.), Cecil Textbook of Medicine, 21 st ed., WB Saunders, Philadelphia, pp.770-773.

Tietz N.W. (1990), Clinical guide to laboratory tests. 2nd ed. Philadelphia, WB Saun-ders.

Van Hoof V.O. and Broe M.E. (1994), Interpretation and clinical significance of alkaline phosphatase isoenzyme patterns, Crti. Rev. Clin. Lab. Sci., 31,197-293.

Vrioni G., Helen S., Myrto K., Konstantinos, M.K. and Haris C. (2011), Determination of pseudocholinesterase serum activity among Agrinion pesticide applicators pre- and post-exposed to organophosphates (fenthion and dimethoate), Toxicol. Environ. Chem., 93, 177-187.

World Health Organization/UNEP (1990), Public Health Impact of Pesticides Used in Agriculture. WHO, Geneva.

Yassi A., Kjellstrom T., Kok T.K. and Gudotli T.L. (2001), Basic Environmental Health, World Health Organization. London, U.K.: Oxford University Press.

Zeinalov T.A. and Gorkin V.Z. (1990), Characteristics of changes in amine oxidase activity during pesticide poisoning, Vopr. Med. Khim., 36, 78-81. 